\title{
Dietary Grape (Vitis vinifera) Seed Powder and Zn-Gly Chelate Complex for Mitigating Heat Stress in Broiler Chickens: Growth Parameters, Malondialdehyde, Paraoxonase-1, and Antibody Titer
}

\author{
Muhammad Israr ${ }^{1}$, Naila Chand ${ }^{1}$, Rifat Ullah Khan ${ }^{2} * *$ (D) Ibrahim A. Alhidary ${ }^{3}$, Mutassim M. Abdelrahman ${ }^{3}$, \\ Hani Hassan Al-Baddani ${ }^{3}$, Vito Laudadio ${ }^{4}$ and Vincenzo Tufarelli ${ }^{4, *}$ (B)
}

check for updates

Citation: Israr, M.; Chand, N.; Khan, R.U.; Alhidary, I.A.; Abdelrahman, M.M.; Al-Baddani, H.H.; Laudadio, V.; Tufarelli, V. Dietary Grape (Vitis vinifera) Seed Powder and Zn-Gly Chelate Complex for Mitigating Heat Stress in Broiler Chickens: Growth Parameters, Malondialdehyde, Paraoxonase-1, and Antibody Titer. Agriculture 2021, 11, 1087. https:// doi.org/10.3390/agriculture11111087

Academic Editor:

Maria Grazia Cappai

Received: 16 October 2021

Accepted: 28 October 2021

Published: 3 November 2021

Publisher's Note: MDPI stays neutral with regard to jurisdictional claims in published maps and institutional affiliations.

Copyright: (c) 2021 by the authors. Licensee MDPI, Basel, Switzerland. This article is an open access article distributed under the terms and conditions of the Creative Commons Attribution (CC BY) license (https:// creativecommons.org/licenses/by/ $4.0 /)$.
1 Department of Poultry Sciences, Faculty of Animal Husbandry and Veterinary Sciences, The University of Agriculture, Peshawar 25120, Pakistan; israrm@gmail.com (M.I.); naila@aup.edu.pk (N.C.)

2 Faculty of Animal Husbandry \& Veterinary Sciences, College of Veterinary Sciences, The University of Agriculture, Peshawar 25120, Pakistan

3 Department of Animal Production, College of Food and Agriculture Sciences, King Saud University, Riadh 11362, Saudi Arabia; ialahidary@ksu.edu.sa (I.A.A.); amutassim@ksu.edu.sa (M.M.A.); halbaddani@ksu.edu.sa (H.H.A.-B.)

4 Department of DETO, Section of Veterinary Science and Animal Production, University of Bari "Aldo Moro", Valenzano, 70010 Bari, Italy; vito.laudadio@uniba.it

* Correspondence: rukhan@aup.edu.pk (R.U.K.); vincenzo.tufarelli@uniba.it (V.T.)

Abstract: A total of 300 day old broiler chicks (Hubbard) were assigned to 30 floor pens (10 birds per pen) under cyclic heat stress. Three diets including a control, as well as two levels of grape seed powder (GSP) and zinc (OZ) at the rates of $2.5 \mathrm{~g} / \mathrm{kg} \mathrm{GSP}+50 \mathrm{mg} / \mathrm{kg} \mathrm{OZ}$ and $5 \mathrm{~g} / \mathrm{kg} \mathrm{GSP}+50 \mathrm{mg} / \mathrm{kg}$ $\mathrm{OZ}$, were supplied to the broilers for 35 days. According to the results, broiler feed intake improved $(p<0.05)$ in GSP + OZ groups from 3-5 weeks and on an overall basis compared to the control diet. Body weight increased $(p<0.05)$ in GSP-5 + OZ-50 during weeks $2-5$ and on an overall basis. The findings indicated that feed conversion ratio (FCR) decreased $(p<0.05)$ during week 5 in broilers supplemented with GSP-5 + OZ-50. The antibody titer (HI) against Newcastle disease (ND) was higher $(p<0.05)$ in GSP + OZ groups compared to control treatment. The value of malondialdehyde (MDA) decreased $(p<0.05)$ under GSP + OZ diets compared to control. Moreover, paraoxonase (PON1) was higher $(p<0.05)$ in GSP + OZ groups compared to untreated broilers. In conclusion, GSP + OZ positively supported growth traits, reduced MDA, and augmented PON1 and HI titer against ND in broilers exposed to heat stress.

Keywords: broiler; grape seeds; heat stress; zinc; redox balance

\section{Introduction}

The definition of heat stress is not conclusive among the scientists. Broadly speaking, when the environmental temperature exceeds the physical temperature, this may result in impaired health and performance of broilers [1]. Generally, from the poultry point of view, when the environmental temperature goes up to $25^{\circ} \mathrm{C}$, birds are considered to be heat-stressed [2]. Heat stress negatively affects the growth performance and health of broilers $[3,4]$. Heat stress is a major limiting factor that can cause significant economic losses every year owing to poor performance, immunity, and health [5].

Zinc $(\mathrm{Zn})$ is needed for a number of physiological functions in animals [6-8]. Zinc is highly sensitive and affected by many factors, which may result in deficiency in the body [9]. Mostly inorganic $\mathrm{Zn}$ is used in the poultry diet in the form of oxides and sulfates; these $\mathrm{Zn}$ forms are known for a number of negative impacts such as less absorption, high hydrophobicity, irritation of gastrointestinal mucosa, low bioavailability, and increased 
environmental excretion $[7,10,11]$. Recently, organic Zn chelates have become more popular in poultry nutrition. Studies have reported enhanced body weight gain and feed efficiency in broilers fed different forms of organic $\mathrm{Zn}[9,11-13]$. There are continuous efforts to find a novel organic complex of $\mathrm{Zn}$, which shows better bioavailability and enhanced growth traits in poultry. Recently, we found that Zn combined with glycine (Gly) improved growth, intestinal features, and redox balance in broilers under heat stress [7].

Every year in the EU, almost 2.5 million metric tons of food waste and residues are generated, yet only $40 \%$ is recycled [14]. Agro-industrial byproducts are rich in high digestible fiber, protein, and lipids and frequently reused due to the increased focus on circular economy in the agri-food system [15]. Grape (Vitis vinifera) is a well-known fruit grown worldwide. It is a valuable source of flavonoids and polyphenols. Most of the flavonoids of grapes are easily absorbed in the small intestines, while others are metabolized into phenolic acids in the colon by the microbiome [16]. In a previous study, Viveros et al. [17] concluded that grape seed extract decreased the count of potential pathogenic bacteria such as Clostridium and increased the number of beneficial bacteria such as Enterococcus in broilers. Furthermore, Wang et al. [18] found that grape seed extract improved the weight gain and enhanced the antioxidant capacity of broilers exposed to Eimeria tenella infection. Recently, Chand et al. [8] concluded that grape seed powder ameliorated the growth curve and lesion score in broilers induced by Eimeria tenella infection. In addition, Vlaicu et al. [19] concluded that 3\% grape seed meal in combination with $9 \%$ rapeseed significantly improved the total phenolic contents and antioxidant in eggs of 50 week old Tetra SL laying hens. Romero et al. [20] found that a combination of grape seed and skin supplementation reduced lipid peroxidation (malondialdehyde) in broiler chicken preserved meat.

To date, little information is available on the effect of dietary supplementation of grape seed powder on broilers growth, immunity, and antioxidant capacity during heat stress. Most of the past studies reported an improvement in the growth performance of broilers supplemented with byproducts/waste/pomace of grapes [21-24]. Little attention has been given to the effect of grape seed powder on broiler health and production. It is speculated that grape seeds alone cannot help to alleviate the heat stress; therefore, we propose that a small quantity of $\mathrm{Zn}$ may work synergistically with grape seeds to decrease the negative effects of heat stress.

Therefore, the purpose of the current study was to assess the individual and combined effects of Zn-Gly chelate and grape seed powder on the growth performance, malondialdehyde, paraoxonase-1, and antibody titer against Newcastle disease in broilers under heat stress conditions.

\section{Materials and Methods}

The study was conducted according to the guidelines of the Declaration of Helsinki and approved by the Ethics Committee of the Faculty of Animal Husbandry and Veterinary Sciences, the University of Agriculture, Peshawar (14/PS/2020).

\subsection{Experimental Design and Bird Management}

Fresh red grape (Vitis vinifera) seeds were acquired from a local source and rinsed with purified water before being dried $\left(30^{\circ} \mathrm{C}\right)$ in the shade for 2 weeks at room temperature. After that, the seeds were crushed in an electric grinder machine into a fine powder. A total of 300 day old male broiler chicks (Hubbard hybrid), with an average weight of $43.4 \pm 0.1 \mathrm{~g}$, were assigned to 30 floor pens with 10 birds per pen, all of which were bedded with wood shaving. Each enclosure was $160 \mathrm{~cm} \times 240 \mathrm{~cm}$ in size and came with circular feeders and drinkers. Throughout the research, birds had unlimited access to food and water from feeders and drinkers. Vaccinations against pathogens, such as Newcastle disease (ND), were given to the birds on a regular basis. Table 1 presents the basic dietary composition. For the first week, the birds were exposed to fluorescent lights for $23 \mathrm{~h}$, followed by a $20 \mathrm{~h} / 4 \mathrm{~h} \mathrm{light/dark}$ cycle. This experiment was conducted in an open-sided house under 
summer conditions of the local environment. The data collected were the natural status of temperature and humidity at that specific hour. As indicated in Table 2, birds were subjected to a cyclic heat stress cycle in the environment (7-35 days).

Table 1. Ingredients and chemical composition of basal diets fed to broiler chickens.

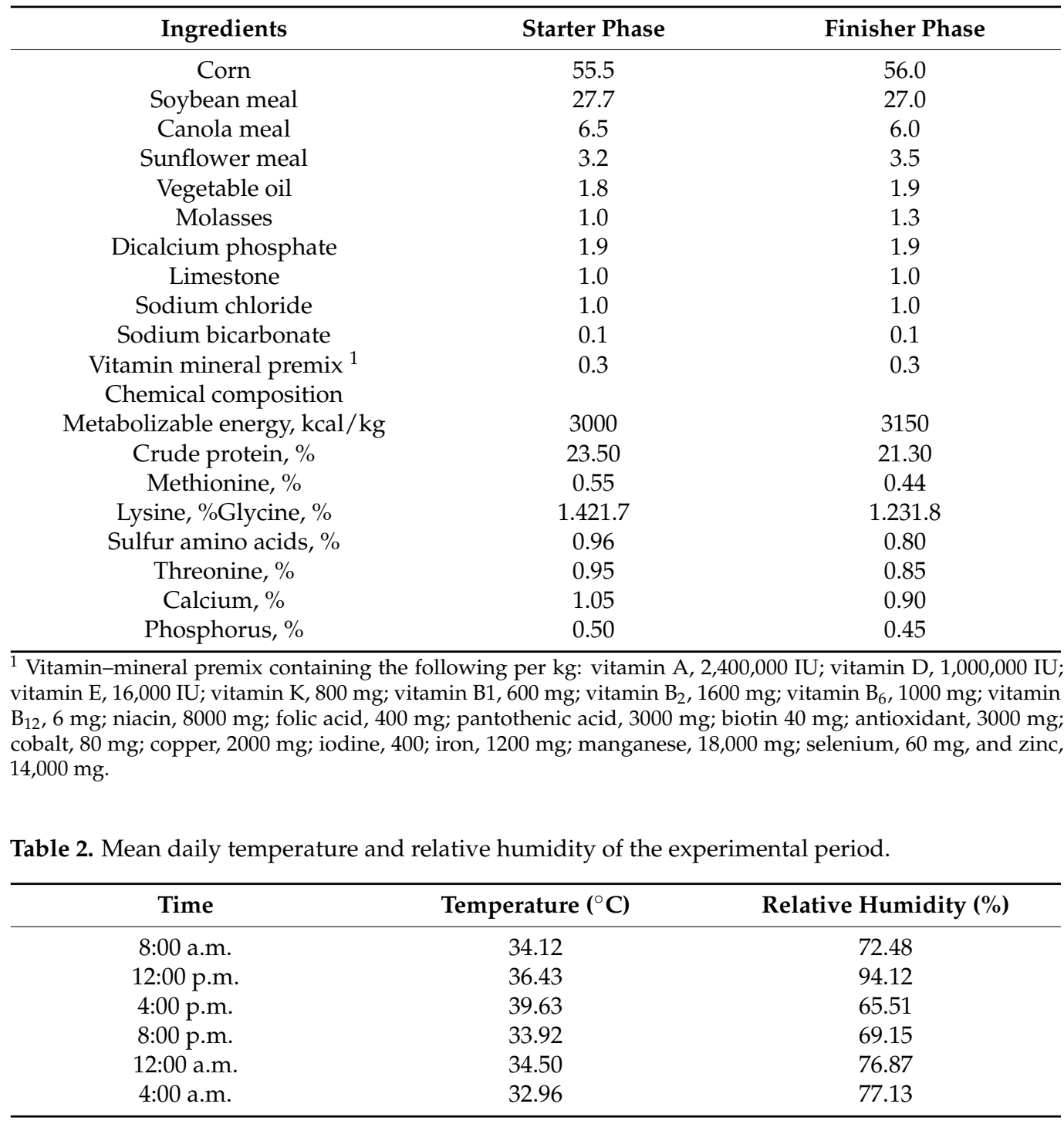

Three diets were prepared and allocated in a completely randomized design consisting of a control (basal diet) and two levels of grape seed powder (GSP) and zinc-glycine chelate (OZ) at the rates of $2.5 \mathrm{~g} / \mathrm{kg}$ GSP $+50 \mathrm{mg} / \mathrm{kg} \mathrm{OZ}$ and $5 \mathrm{~g} / \mathrm{kg} \mathrm{GSP}+50 \mathrm{mg} / \mathrm{kg} \mathrm{OZ}$, for 35 days including 1 week as an adaptation period. Zn-glycine chelate was included in the basal diet at the expense of corn. The OZ product was Bioplex $\mathrm{Zn}^{\circledR}$ (Alltech Inc, Nicholasville, Kentucky, USA), a chelated Zn proteinate that contained $10 \% \mathrm{Zn}$. The GSP and $\mathrm{OZ}$ were well mixed into the diet. In addition, by adding $\mathrm{Zn}$, the concentration of total $\mathrm{Zn}$ was greater in the treatment groups compared to the control. Feed intake, body weight gain, and feed conversion ratio (FCR) were monitored weekly per pen, with the mean of each parameter recorded over the whole time. Three birds were slaughtered by cervical dislocation in each pen on day 35 , and $3 \mathrm{cc}$ blood samples were collected into glass tubes. Blood samples were centrifuged for $10 \mathrm{~min}$ at $3000 \mathrm{rpm}$, and the serum was kept at $-80^{\circ} \mathrm{C}$ until analysis. 


\subsection{Determination of Malondialdehyde (MDA), Paraoxonase (PON1), and HI Titer against ND}

The thiobarbituric acid (TBA) reaction, originally reported by Ohkawa et al. [25], was used to determine lipid peroxidation in blood samples. TBA's reaction color was spectrophotometrically quantified at $532 \mathrm{~nm}$. The technique of Mackness et al. [26], using phenol as a substrate, was used to detect blood paraoxonase (PON-1). In this case, $1 \mathrm{mM}$ phenylacetate, calcium chloride, and $20 \mathrm{mM}$ Tris $\mathrm{HCl}$ buffer were used to make the working reagent. After diluting the sample 1:3 with buffer before mixing with the substrate, the change in absorbance at $270 \mathrm{~nm}$ was measured for $5 \mathrm{~min}$. The hemagglutination inhibition (HI) assay was used to evaluate the immune response to the ND virus.

\subsection{Statistical Analysis}

A completely randomized design was used to analyze the data in Statistix 8.1 Software. Tukey's test was used to calculate significant differences between experimental groups at a probability threshold of $5 \%$.

\section{Results}

The findings of feed intake in broilers exposed to heat stress in response to different levels of GSP are given in Table 3. At the end of week 2, feed intake increased significantly $(p<0.05)$ only in GSP-5 + OZ-50 compared to the control. The feed intake improved significantly $(p<0.05)$ in GSP + OZ groups from week 3 to 5 and on an overall basis compared to the control. The findings of body weight gain in response to dietary supplementation of GSP and OZ are given in Table 4 , where this parameter increased significantly $(p<0.05)$ in GSP-5 + OZ-50 compared to the control during weeks 2 to 5 and on an overall basis. The results of FCR in broilers exposed to heat stress and dietary supplementation of $\mathrm{OZ}$ and GSP are given in Table 5. The FCR decreased significantly $(p<0.05)$ during week 5 in broilers exposed to heat stress and supplemented with GSP + OZ groups. No significant change was observed during the other weeks and on an overall basis, indicating that the feed efficiency was improved in broilers supplemented with OZ and GSP during the finisher phase when exposed to heat stress.

The effects of OZ and GSP on MDA, PON1, and ND titer on broilers under heat stress conditions are given in Table 6 . The antibody titer against ND was significantly $(p<0.05)$ higher in GSP + OZ groups compared to the control. The value of MDA decreased significantly $(p<0.05)$ in GSP- $2.5+$ OZ groups compared to the control. The blood concentration of PON1 was significantly $(p<0.05)$ higher in GSP + OZ groups compared to the control.

Table 3. Cumulative feed intake $(g \pm S E)$ in broiler chicks fed different levels of zinc-glycine chelate and grape seed powder under summer stress conditions.

\begin{tabular}{cccccc}
\hline Item & Week 2 & Week 3 & Week 4 & Week 5 & Overall \\
\hline Control & $364.70^{\mathrm{b}} \pm 3.57$ & $573.95^{\mathrm{b}} \pm 7.56$ & $691.33^{\mathrm{b}} \pm 5.63$ & $889.07^{\mathrm{c}} \pm 7.35$ & $2519.1^{\mathrm{c}} \pm 17.73$ \\
GSP-2.5 + OZ-50 & $370.38^{\mathrm{ab}} \pm 7.38$ & $600.20^{\mathrm{a}} \pm 4.24$ & $712.33^{\mathrm{a}} \pm 10.73$ & $909.08^{\mathrm{b}} \pm 11.4$ & $2588.3^{\mathrm{b}} \pm 16.95$ \\
GSP-5 + OZ-50 & $376.45^{\mathrm{a}} \pm 7.34$ & $604.48^{\mathrm{a}} \pm 8.54$ & $720.55^{\mathrm{a}} \pm 6.21$ & $927.73^{\mathrm{a}} \pm 10.44$ & $2629.2^{\mathrm{a}} \pm 16.16$ \\
$p$-value & 0.001 & $<0.001$ & 0.001 & 0.001 & $<0.001$ \\
\hline
\end{tabular}

Means within the same column with different superscripts are statistically different $(p<0.05)$. GSP-2.5 + OZ-50: grape seed powder and zinc-glycine chelate at the rates of $2.5 \mathrm{~g} / \mathrm{kg}$ and $50 \mathrm{mg} / \mathrm{kg}$, respectively; GSP-5 + OZ-50: grape seed powder and zinc-glycine chelate at the rates of $5 \mathrm{~g} / \mathrm{kg}$ and $50 \mathrm{mg} / \mathrm{kg}$, respectively. 
Table 4. Body weight gain ( $\mathrm{g} / \mathrm{bird})(\mathrm{g} \pm \mathrm{SE})$ in broiler chicks fed different levels of zinc-glycine chelate and grape seed powder under summer stress conditions.

\begin{tabular}{cccccc}
\hline Item & Week 2 & Week 3 & Week 4 & Week 5 & Overall \\
\hline Control & $251.75^{\mathrm{b}} \pm 6.65$ & $360.50^{\mathrm{b}} \pm 9.46$ & $411.75^{\mathrm{b}} \pm 16.31$ & $453.25^{\mathrm{c}} \pm 6.34$ & $1487.3^{\mathrm{b}} \pm 11.32$ \\
GSP-2.5 + OZ-50 & $253.50^{\mathrm{b}} \pm 5.56$ & $364.25^{\mathrm{ab}} \pm 4.03$ & $429.50^{\mathrm{b}} \pm 10.40$ & $476.00^{\mathrm{b}} \pm 4.69$ & $1508.3^{\mathrm{ab}} \pm 17.66$ \\
GSP-5 + OZ-50 & $262.75^{\mathrm{a}} \pm 4.78$ & $370.50^{\mathrm{a}} \pm 3.10$ & $444.75^{\mathrm{a}} \pm 12.03$ & $469.50^{\mathrm{a}} \pm 4.65$ & $1576.0^{\mathrm{a}} \pm 21.08$ \\
$p^{\mathrm{a}}$-value & 0.049 & 0.0124 & 0.013 & $<0.001$ & 0.032 \\
\hline
\end{tabular}

Means within the same column with different superscripts are statistically different $(p<0.05)$. GSP-2.5 + OZ-50: grape seed powder and zinc-glycine chelate at the rates of $2.5 \mathrm{~g} / \mathrm{kg}$ and $50 \mathrm{mg} / \mathrm{kg}$, respectively; GSP- 5 + OZ-50: grape seeds powder and zinc-glycine chelate at the rates of $5 \mathrm{~g} / \mathrm{kg}$ and $50 \mathrm{mg} / \mathrm{kg}$, respectively.

Table 5. Feed conversion ratio (FCR) $(\mathrm{g} / \mathrm{g} \pm \mathrm{SE}$ ) in broiler chicks fed different levels of zinc-glycine chelate and grape seed powder under summer stress condition.

\begin{tabular}{cccccc}
\hline Item & Week 2 & Week 3 & Week 4 & Week 5 & Overall \\
\hline Control & $1.44 \pm 0.037$ & $1.59 \pm 0.57$ & $1.67 \pm 0.066$ & $1.95^{\mathrm{a}} \pm 0.026$ & $1.69 \pm 0.074$ \\
GSP-2.5 + OZ-50 & $1.45 \pm 0.040$ & $1.64 \pm 0.02$ & $1.61 \pm 0.047$ & $1.90^{\mathrm{b}} \pm 0.031$ & $1.75 \pm 0.073$ \\
GSP-5 + OZ-50 & $1.43 \pm 0.037$ & $1.62 \pm 0.017$ & $1.61 \pm 0.033$ & $1.85^{\mathrm{c}} \pm 0.275$ & $1.66 \pm 0.017$ \\
$p$-value & 0.662 & 0.166 & 0.178 & 0.003 & 0.535 \\
\hline
\end{tabular}

Means within the same column with different superscripts are statistically different $(p<0.05)$. GSP-2.5 + OZ-50: grape seed powder and zinc-glycine chelate at the rates of $2.5 \mathrm{~g} / \mathrm{kg}$ and $50 \mathrm{mg} / \mathrm{kg}$, respectively; GSP-5 + OZ-50: grape seed powder and zinc-glycine chelate at the rates of $5 \mathrm{~g} / \mathrm{kg}$ and $50 \mathrm{mg} / \mathrm{kg}$, respectively.

Table 6. Effect of dietary grape seed powder and zinc-glycine chelate on antibody titer against Newcastle disease (ND), malondialdehyde (MDA), and paraoxonase (PON1) in broiler chicks under summer stress conditions.

\begin{tabular}{cccc}
\hline Groups & ND Titer & MDA $(\mathbf{n m o l} / \mathbf{m L})$ & PON1 $(\boldsymbol{\mu} / \mathbf{m L})$ \\
\hline Control & $4.27^{\mathrm{c}} \pm 0.039$ & $11.09^{\mathrm{a}} \pm 0.88$ & $8.31^{\mathrm{b}} \pm 0.80$ \\
GSP-2.5 + OZ-50 & $5.74^{\mathrm{b}} \pm 0.311$ & $6.42^{\mathrm{b}} \pm 0.55$ & $12.15^{\mathrm{a}} \pm 0.78$ \\
GSP-5 + OZ-50 & $6.78^{\mathrm{a}} \pm 0.428$ & $6.91^{\mathrm{b}} \pm 0.52$ & $12.89^{\mathrm{a}} \pm 0.77$ \\
$p$-value & $<0.001$ & $<0.001$ & $<0.001$ \\
\hline
\end{tabular}

Means within the same column with different superscripts are statistically different $(p<0.05)$. GSP-2.5 + OZ-50: grape seed powder and zinc-glycine chelate at the rates of $2.5 \mathrm{~g} / \mathrm{kg}$ and $50 \mathrm{mg} / \mathrm{kg}$, respectively; GSP-5 + OZ-50: grape seed powder and zinc-glycine chelate at the rates of $5 \mathrm{~g} / \mathrm{kg}$ and $50 \mathrm{mg} / \mathrm{kg}$, respectively.

\section{Discussion}

In the current study, it was found that feed intake and body weight gain improved significantly in GSP + OZ-supplemented birds under heat stress. On the other hand, it is evident that the feed intake and corresponding weight gain in birds exposed to heat stress were significantly decreased in the control group. In heat-stressed birds, energy is diverted from production system toward the protective strategy against heat stress [27,28]. Organic Zn supplementation has been known to ameliorate and prevent the negative impacts of heat stress in broilers [28-30].

Under heat stress, the demand for energy increases, which results in increased glycogenesis, suppression of appetite, gastric lesions, and disruption of immunological mechanisms. In addition, higher temperature with relative humidity causes airway desiccation and dehydration in birds. Such factors may directly or indirectly influence feed consumption, weight gain, and feed efficiency in birds. Zinc plays a vital role in several metabolic pathways. The absorption of $\mathrm{Zn}$ is influenced by metallothionine in the enterocytes. It has been suggested that the organic form of $\mathrm{Zn}$ increases the absorptive and utilization capacity of feed [7]. In addition, organic Zn provides higher bioavailability and increases the digestibility of nutrients. Furthermore, organic $\mathrm{Zn}$ remains for longer period in the gut and is more ecofriendly. There are conflicting results regarding the use of different byproducts of grapes on the performance of broilers under heat stress with limited or no improvement [21-23]. However, recently, Chand et al. [8] reported improved feed 
intake, weight gain, and feed efficiency in response to Zn-Gly and GSP in birds exposed to Eimeria tenella challenge. It seems from the findings of Chand et al. (2021) and the current study that organic Zn works best in combination with GSP. Grape seed contains flavanol monomers (epicatechin 3-O-gallate, epicatechin, and catechin), flavanol dimers (procyanidin gallate, procyanidin $\mathrm{B} 3$, procyanidin $\mathrm{B} 2$, and procyanidin $\mathrm{B} 1$ ), flavanol trimers (procyanidin trimer and procyanidin C1), flavanol tetramers (procyanidin tetramer and procyanidin cinnamtannin A2), and phenolic acids (coutaric acid, fertaric acid, caftaric acid, and gallic acid) (Romero et al. [20]. Recently, Romero et al. (2021) reported that grape seed at the rate of $30 \mathrm{~g} / \mathrm{kg}$ improved the weight gain and feed efficiency in broilers under thermoneutral conditions. However, detrimental effects of grape seed supplementation have also been reported on the growth performance in broilers [17,31], depending upon the type and dose of polyphenols present in the grape seeds [20]. The improvement in growth traits of broilers could also be due to the extensive intestinal utilization and microbial metabolism of grape polyphenols as reported in poultry [31].

Heat stress is well known to reduce immune response in broilers through decreasing the weight of lymphoid organs and antibody production [32,33]. The Zn-glycine complex has a beneficial impact on the immune system [9]. Zn-glycine at the rate of $50 \mathrm{mg} / \mathrm{kg}$ improved the antibody titer against ND in broilers under thermoneutral conditions [7]. This again justifies our conclusion that combined doses of OZ and GSP work best in improving of immune status of birds during heat stress. In the study of Hosseini-Vashon et al. [23], the antibody titer against ND was not affected by different levels of grape pomace in broilers during heat stress, justifying our findings that GSP works best when combined with Zn.

Heat stress directly affects the oxidant/antioxidant status of the birds. Heat stress directly reduces the activity of antioxidant enzymes and molecules $[1,5]$, but enhances the plasma concentration of MDA [34]. In the current study, supplementation of GSP and OZ reduced serum MDA in heat stress broilers. Grapes are a rich source of polyphenols, which exhibit strong antioxidant effects by neutralizing oxidative molecules [23,35]. Polyphenolic chemicals and other plant-derived secondary metabolites can be found in a variety of foods, including fruits, leaves, roots, and seeds, and they constitute a significant component of both human and animal diets [36]. They have antioxidant properties, they can scavenge free radicals, and their consumption has been associated with a lower risk of diseases such as cancer, cardiovascular disease, and chronic inflammation [37]. In broilers, supplementation of both grape seeds and pomace resulted in improved antioxidant status in the blood and meat, which has been associated with a high concentration of alpha- and gammatocopherol [20,31]. Alpha-tocopherol oxidizes itself during the process of lipid peroxidation, and it is thought to be recycled by grape procyanidins [38].

In the current study, serum PON1 rose significantly in GSP + OZ groups compared to the control. PON1 is considered an antioxidant-based enzyme, and its level was found to be improved as a result of some feed additives in broilers under heat stress $[7,39,40]$. $\mathrm{Zn}$ is known for its important role in the antioxidant system by suppressing free radicals [41]. It is also an essential part of the antioxidant enzymes in blood. Therefore, we speculate that $\mathrm{Zn}$ also has a beneficial impact on the status of PON1. Similarly, in the current study, GSP doses improved the PON1 concentration. This is the first study reporting PON1 concentration to be influenced by GSP. It could not be confirmed whether the effect was due to polyphenols, and it is speculated that polyphenols in grape are responsible for such a beneficial effect in broilers during heat stress.

\section{Conclusions}

According to the present findings, it can be concluded that GSP + OZ positively supported body weight gain, reduced MDA, and augmented PON1 and HI titer against ND in broiler chickens exposed to heat stress. 
Author Contributions: Conceptualization, N.C.; methodology, N.C.; validation, I.A.A. and R.U.K.; formal analysis, M.I.; investigation, M.I.; data curation, R.U.K. and V.T.; writing-original draft preparation, M.I. and R.U.K.; writing—review and editing, R.U.K., I.A.A., M.M.A., H.H.A.-B., V.T., and V.L. All authors have read and agreed to the published version of the manuscript.

Funding: This work was funded by the Deanship of Scientific Research at King Saud University (No. RG-1436-021).

Institutional Review Board Statement: This study was approved by the Departmental Committee on Ethics and Animal Welfare, Faculty of Animal Husbandry and Veterinary Sciences, the University of Agriculture, Peshawar.

Acknowledgments: The authors (I.A.A, M.M.A and H.H.A) extend their appreciation to the Deanship of Scientific Research at King Saud University for funding this work through research project number RG-1436-021.

Conflicts of Interest: The authors declare no conflict of interest.

\section{References}

1. Khan, R.U.; Naz, S.; Nikousefat, Z.; Selvaggi, M.; Laudadio, V.; Tufarelli, V. Effect of ascorbic acid in heat-stressed poultry. World's Poult. Sci. J. 2012, 68, 477-490. [CrossRef]

2. Khan, R.; Naz, S.; Dhama, K. Chromium: Pharmacological Applications in Heat-Stressed Poultry. Int. J. Pharmacol. 2014, 10, 213-217. [CrossRef]

3. Chand, N.; Naz, S.; Rehman, Z.; Khan, R. Blood biochemical profile of four fast-growing broiler strains under high ambient temperature. Appl. Biol. Chem. 2018, 61, 273-279. [CrossRef]

4. Hafeez, A.; Akram, W.; Sultan, A.; Konca, Y.; Ayasan, T.; Naz, S.; Shahzada, W.; Khan, R.U. Effect of dietary inclusion of taurine on performance, carcass characteristics and muscle micro-measurement in broilers under cyclic heat stress. Ital. J. Anim. Sci. 2021, 20, 872-877. [CrossRef]

5. Khan, R.; Naz, S.; Nikousefat, Z.; Tufarelli, V.; Javdani, M.; Rana, N.; Laudadio, V. Effect of vitamin E in heat-stressed poultry. World's Poult. Sci. J. 2011, 67, 469-478. [CrossRef]

6. Naz, S.; Idris, M.; Khalique, M.A.; Alhidary, I.A.; Abdelrahman, M.M.; Khan, R.U.; Ahmad, S. The activity and use of zinc in poultry diet. World Poult. Sci. J. 2016, 72, 159-167. [CrossRef]

7. Chand, N.; Khan, R.U.; Shah, M.; Naz, S.; Tinelli, A. Zinc source modulates zootechnical characteristics, intestinal features, humoral response and paraoxonase (PON1) activity in broilers. Trop. Anim. Health Prod. 2020, 52, 511-515. [CrossRef] [PubMed]

8. Chand, N.; Ali, P.; Alhidary, I.; Abdelrahman, M.; Albadani, H.; Khan, M.; Seidavi, A.; Laudadio, V.; Tufarelli, V.; Khan, R. Protective Effect of Grape (Vitis vinifera) Seed Powder and Zinc-Glycine Complex on Growth Traits and Gut Health of Broilers Following Eimeria tenella Challenge. Antibiotics 2021, 10, 186. [CrossRef] [PubMed]

9. Jarosz, L.; Marek, A.; Grądzki, Z.; Kwiecień, M.; Żylińska, B.; Kaczmarek, B. Effect of feed supplementation with zinc glycine chelate and zinc sulfate on cytokine and immunoglobulin gene expression profiles in chicken intestinal tissue. Poult. Sci. 2017, 96, 4224-4235. [CrossRef]

10. Cao, J.; Henry, P.R.; Davis, S.R.; Cousins, R.J.; Miles, R.D.; Littell, R.C.; Ammerman, C.B. Relative bioavailability of organic zinc sources based on tissue zinc and metallothionein in chicks fed conventional dietary zinc concentrations. Anim. Feed. Sci. Technol. 2002, 101, 161-170. [CrossRef]

11. Min, Y.N.; Liu, F.X.; Qi, X.; Ji, S.; Cui, L.; Wang, Z.P.; Gao, Y.P. Effects of organic zinc on tibia quality, mineral deposit, and metallothionein expression level of aged hens. Poult. Sci. 2018, 99, 366-372. [CrossRef]

12. Jahanian, R.; Rasouli, E. Effects of dietary substitution of zinc-methionine for inorganic zinc sources on growth performance, tissue zinc accumulation and some blood parameters in broiler chicks. J. Anim. Physiol. Anim. Nutr. 2015, 99, 50-58. [CrossRef] [PubMed]

13. Akhavan-Salamat, H.; Ghasemi, H.A. Effect of different sources and contents of zinc on growth performance, carcass characteristics, humoral immunity and antioxidant status of broiler chickens exposed to high environmental temperatures. Livest. Sci. 2019, 223, 76-83. [CrossRef]

14. European Commission. Food Waste. Stop Food Waste Initiative, Based on 2012 Data. 2016. Available online: http://ec.europa. eu/food/safety/food_waste/stop/index_en.htm (accessed on 19 September 2021).

15. Nudda, A.; Buffa, G.; Atzori, A.; Cappai, M.; Caboni, P.; Fais, G.; Pulina, G. Small amounts of agro-industrial byproducts in dairy ewes diets affects milk production traits and hematological parameters. Anim. Feed. Sci. Technol. 2019, 251, 76-85. [CrossRef]

16. Azizi, M.; Seidavi, A.; Ragni, M.; Laudadio, V.; Tufarelli, V. Practical applications of agricultural wastes in poultry feeding in Mediterranean and Middle East regions. Part 1: Citrus, grape, pomegranate and apple wastes. World's Poult. Sci. J. 2018, 74, 489-498. [CrossRef] 
17. Viveros, A.; Chamorro, S.; Pizarro, M.; Arija, I.; Centeno, C.; Brenes, A. Effects of dietary polyphenol-rich grape products on intestinal microflora and gut morphology in broiler chicks. Poult. Sci. 2011, 90, 566-578. [CrossRef]

18. Wang, M.L.; Suo, X.; Gu, J.H.; Zhang, W.W.; Fang, Q.; Wang, X. Influence of Grape Seed Proanthocyanidin Extract in Broiler Chickens: Effect on Chicken Coccidiosis and Antioxidant Status. Poult. Sci. 2008, 87, 2273-2280. [CrossRef]

19. Vlaicu, P.A.; Panaite, T.D.; Turcu, R.P. Enriching laying hens eggs by feeding diets with different fatty acid composition and antioxidants. Sci. Rep. 2021, 11, 1-12. [CrossRef] [PubMed]

20. Romero, C.; Nardoia, M.; Arija, I.; Viveros, A.; Rey, A.; Prodanov, M.; Chamorro, S. Feeding Broiler Chickens with Grape Seed and Skin Meals to Enhance $\alpha$ - and $\gamma$-Tocopherol Content and Meat Oxidative Stability. Antioxidants 2021, 10, 699. [CrossRef] [PubMed]

21. Hajati, H.; Hassanabadi, A.; Golian, A.; Nassiri-Moghaddam, H.; Nassiri, M.R. The effect of grape seed extract and vitamin C feed supplementation on some blood parameters and HSP70 gene expression of broiler chickens suffering from chronic heat stress. Ital. J. Anim. Sci. 2015, 14, 3273-3281. [CrossRef]

22. Mazur-Kuśnirek, M.; Antoszkiewicz, Z.; Lipiński, K.; Kaliniewicz, J.; Kotlarczyk, S.; Żukowski, P. The effect of polyphenols and vitamin $\mathrm{E}$ on the antioxidant status and meat quality of broiler chickens exposed to high temperature. Arch. Anim. Nutr. 2019, 73, 111-126. [CrossRef]

23. Hosseini-Vashan, S.J.; Safdari-Rostamabad, M.; Piray, A.H. The growth performance, plasma biochemistry indices, immune system, antioxidant status, and intestinal morphology of heat stressed broiler chickens fed grape (Vitis vinifera) pomace. Anim. Feed. Sci. Technol. 2020, 259, 114343. [CrossRef]

24. Tufarelli, V.; Baghban-Kanani, P.; Azimi-Youvalari, S.; Hosseintabar-Ghasemabad, B.; Slozhenkina, M.; Gorlov, I.; Viktoronova, F.M.; Seidavi, A.; Laudadio, V. Effect of dietary flaxseed meal supplemented with dried tomato and grape pomace on performance traits and antioxidant status of laying hens. Anim. Biotechnol. 2021, 47, 1-8. [CrossRef] [PubMed]

25. Ohkawa, H.; Ohishi, N.; Yagi, K. Assay for lipid peroxides in animal tissues by thiobarbituric acid reaction. Anal. Biochem. 1979, 95, 351-358. [CrossRef]

26. Mackness, B.; Durrington, P.N.; Mackness, M.I. Human serum paraoxonase. In General Pharmacology: The Vascular System; Elsevier: Amsterdam, The Netherlands, 1998; Volume 31, pp. 329-336.

27. Koch, F.; Thom, U.; Albrecht, E.; Weikard, R.; Nolte, W.; Kuhla, B.; Kuehn, C. Heat stress directly impairs gut integrity and recruits distinct immune cell populations into the bovine intestine. Proc. Natl. Acad. Sci. USA 2019, 116, 10333-10338. [CrossRef] [PubMed]

28. Abuajamieh, M.; Abdelqader, A.; Irshaid, R.; Hayajneh, F.M.F.; Al-Khaza'Leh, J.; Al-Fataftah, A.-R. Effects of organic zinc on the performance and gut integrity of broilers under heat stress conditions. Arch. Anim. Breed. 2020, 63, 125-135. [CrossRef]

29. Pearce, S.C.; Sanz-Fernandez, M.V.; Torrison, J.L.; Wilson, M.E.; Baumgard, L.H.; Gabler, N.K. Dietary organic zinc attenuates heat stress-induced changes in pig intestinal integrity and metabolism12. J. Anim. Sci. 2015, 93, 4702-4713. [CrossRef]

30. Khan, R.U.; Naz, S.; Ullah, H.; Ullah, Q.; Laudadio, V.; Bozzo, G.; Tufarelli, V. Physiological dynamics in broiler chickens under heat stress and possible mitigation strategies. Anim. Biotechnol. 2021, 1-10. [CrossRef]

31. Chamorro, S.; Romero, C.; Brenes, A.; Sánchez-Patán, F.; Bartolomé, B.; Viveros, A.; Arija, I. Impact of a sustained consumption of grape extract on digestion, gut microbial metabolism and intestinal barrier in broiler chickens. Food Funct. 2019, 10, 1444-1454. [CrossRef]

32. Zia Ur Rahman, Z.; Chand, N.; Khan, R.U. The effect of vitamin E, L-carnitine and ginger on production traits, immune response and antioxidant status in two broiler strains exposed to chronic heat stress. Environ. Sci. Pollut. Res. 2017, 24, 26851-26857. [CrossRef] [PubMed]

33. Kpomasse, C.C.; Oke, O.E.; Houndonougbo, F.M.; Tona, K. Broiler production challenges in the tropics: A review. Veter-Med. Sci. 2021, 7, 831-842. [CrossRef] [PubMed]

34. Ahmad, M.; Chand, N.; Khan, R.U.; Ahmad, N.; Khattak, I.; Naz, S. Dietary supplementation of milk thistle (Silybum marianum): Growth performance, oxidative stress, and immune response in natural summer stressed broilers. Trop. Anim. Health Prod. 2019, 52, 711-715. [CrossRef] [PubMed]

35. Brenes, A.; Viveros, A.; Goñi, I.; Centeno, C.; Sáyago-Ayerdy, S.; Arija, I.; Saura-Calixto, F. Effect of Grape Pomace Concentrate and Vitamin E on Digestibility of Polyphenols and Antioxidant Activity in Chickens. Poult. Sci. 2008, 87, 307-316. [CrossRef] [PubMed]

36. Alldritt, I.; Whitham-Agut, B.; Sipin, M.; Studholme, J.; Trentacoste, A.; Tripp, J.A.; Cappai, M.G.; Ditchfield, P.; Devièse, T.; Hedges, R.E.M.; et al. Metabolomics reveals diet-derived plant polyphenols accumulate in physiological bone. Sci. Rep. 2019, 9, 1-12. [CrossRef] [PubMed]

37. Karami, S.; Rahimi, M.; Babaei, A. An overview on the antioxidant, anti-inflammatory, antimicrobial and anti-cancer activity of grape extract. Biomed. Res. Clin. Pr. 2018, 3, 1-4. [CrossRef]

38. Iglesias, J.; Pazos, M.; Torres, J.L.; Medina, I. Antioxidant mechanism of grape procyanidins in muscle tissues: Redox interactions with endogenous ascorbic acid and $\alpha$-tocopherol. Food Chem. 2012, 134, 1767-1774. [CrossRef]

39. Chand, N.; Muhammad, S.; Khan, R.U.; Alhidary, I.A.; Ziaur, R. Ameliorative effect of synthetic $\gamma$-aminobutyric acid (GABA) on performance traits, antioxidant status and immune response in broiler exposed to cyclic heat stress. Environ. Sci. Pollut. Res. 2016, 23, 23930-23935. [CrossRef] [PubMed] 
40. Safiullah; Chand, N.; Khan, R.U.; Naz, S.; Ahmad, M.; Gul, S. Effect of ginger (Zingiber officinale Roscoe) and organic selenium on growth dynamics, blood melanodialdehyde and paraoxonase in broilers exposed to heat stress. J. Appl. Anim. Res. 2019, 47, 212-216. [CrossRef]

41. Rahman, H.; Qureshi, M.S.; Khan, R. Influence of Dietary Zinc on Semen Traits and Seminal Plasma Antioxidant Enzymes and Trace Minerals of Beetal Bucks. Reprod. Domest. Anim. 2014, 49, 1004-1007. [CrossRef] 